Selcuk Journal of Agriculture and Food Sciences

http://sjafs.selcuk.edu.tr/sjafs/index

Research Article
SJAFS

(2020) 34 (1), 65-69

e-ISSN: 2458-8377

DOI:10.15316/SJAFS.2020.196

\title{
Seed Vigor Changes of Forage Pea Cultivars Based on Seed Color
}

\author{
Süleyman AVCI ${ }^{1, *}$, Musa SAYLAN ${ }^{1}$, Mehmet Demir KAYA ${ }^{1}$ \\ ${ }^{1}$ Eskişehir Osmangazi University, Faculty of Agriculture, Department of Field Crops, Eskişehir, Turkey
}

\begin{tabular}{l}
\hline ARTICLE INFO \\
\hline Article history: \\
Received date: 20.12 .2019 \\
Accepted date: 05.02 .2020 \\
\hline Edited by: \\
Ali KAHRAMAN; Selçuk University, \\
Turkey \\
Reviewed by: \\
Abdullah ÖZKÖSE; Selçuk University, \\
Turkey \\
Zeki ACAR; Ondokuz Mayls University, \\
Turkey \\
Cahit BALABANLI; Applied Sciences \\
University of Isparta, Turkey \\
Cengiz SANCAK; Ankara University, \\
Turkey \\
\hline Keywords: \\
Pisum arvense L. \\
Seed vigor \\
Accelerated ageing \\
Germination \\
Seedling growth
\end{tabular}

\section{Introduction}

Forage pea (Pisum sativum subsp. arvense (L.), an annual forage legume adapting in the cool season, is used for hay and seed production in feeding ruminants. It might be also cultivated as green manuring to enhance soil fertility. It is a high-quality feed source for livestock as roughage and intensive feeding. The nutritional value of forage pea as roughage and seed is about $18-20 \%$ and $20-30 \%$ crude protein, respectively (Mishra et al. 2010; Tan et al. 2012; Açıkgöz 2001). Because it fixes nitrogen into the soil between 5-15 $\mathrm{kg} / \mathrm{da}$ and leaves a clean stubble for subsequent crops, it has a high potential in winter sowing in irrigated and fallow land in the central region of Turkey (Parr et al. 2011; Uzun et al. 2012). Therefore, forage pea sown area (104 $377 \mathrm{da})$ and green production (210 706 tonnes) in Turkey has increased by 3 times in the last 5 years (TUIK 2018).

Variations in seed coat color in forage pea are associated with seed harvest in different development stag-

\footnotetext{
* Corresponding author email: savci@ogu.edu.tr
}

es of fruit and some genetic differences (Atış et al. 2011). The seed coat color might be different in the same varieties due to different ripening period of pods. In some research, it was reported that different seed coat colors affect water imbibition and seed quality characteristics in various legumes. Dark colored seeds in Pisum sativum L. (Atak et al. 2008) and in Lotus sp. (Bhatt et al. 2016) indicated that superior seed quality characteristics were observed in dark colored seeds than light ones. In contrary of these findings, light colored seeds had higher germination rate and lower EC values in Vigna subterranea L (Mandizvo and Odindo 2019) and in Cicer arietinum L. (Anuradha et al. 2009. Also, green colored seeds gave better seed vigor and quality than dark ones (Ertekin and Kirdar 2010; Atış et al. 2011).

Despite the high rate of different seed coat colors in forage pea varieties, no previous studies have been conducted on seed vigor and quality. The aim of this study was to investigate the effect of three seed colors (brown, green and army green) on germination and seed vigor characteristics of three forage pea varieties with purple flowers (Taşkent, Özkaynak and Töre). 


\section{Materials and Methods}

Forage pea genotypes of Özkaynak, Töre and Taşkent purchased from local seed suppliers were produced at the experimental fields of Eskişehir Osmangazi University, Turkey in 2018. Until the start of the experiment, the seeds were stored at $4^{\circ} \mathrm{C}$. The three seed colors were visually screened and separated by previously reported as brown, green and army green by Santos et al. (2019) as shown in Figure 1.

Germination test were performed by four replicates of 50 seeds from each cultivar and seed color. The seeds were germinated in three rolled filter papers with
$7 \mathrm{~mL}$ of distilled water. To avoid water evaporation, the rolled papers were put into a sealed plastic bag and transferred to incubator arranged at $20 \pm 1^{\circ} \mathrm{C}$ in the dark. A two millimeter of root protrusion was considered as germination criterion. The germinated seeds were daily counted and $2^{\text {nd }}$ day germination expresses two days after the start of germination test. Fnal germination percentage (FGP) was recorded at $8^{\text {th }}$ day of germination (ISTA 2003). The germination speed was evaluated by using mean germination time described by follows: $\mathrm{MGT}=\Sigma \mathrm{Dn} / \Sigma \mathrm{n}$

Where D is the number of newly germinated seeds on each day and $n$ is days of counting.

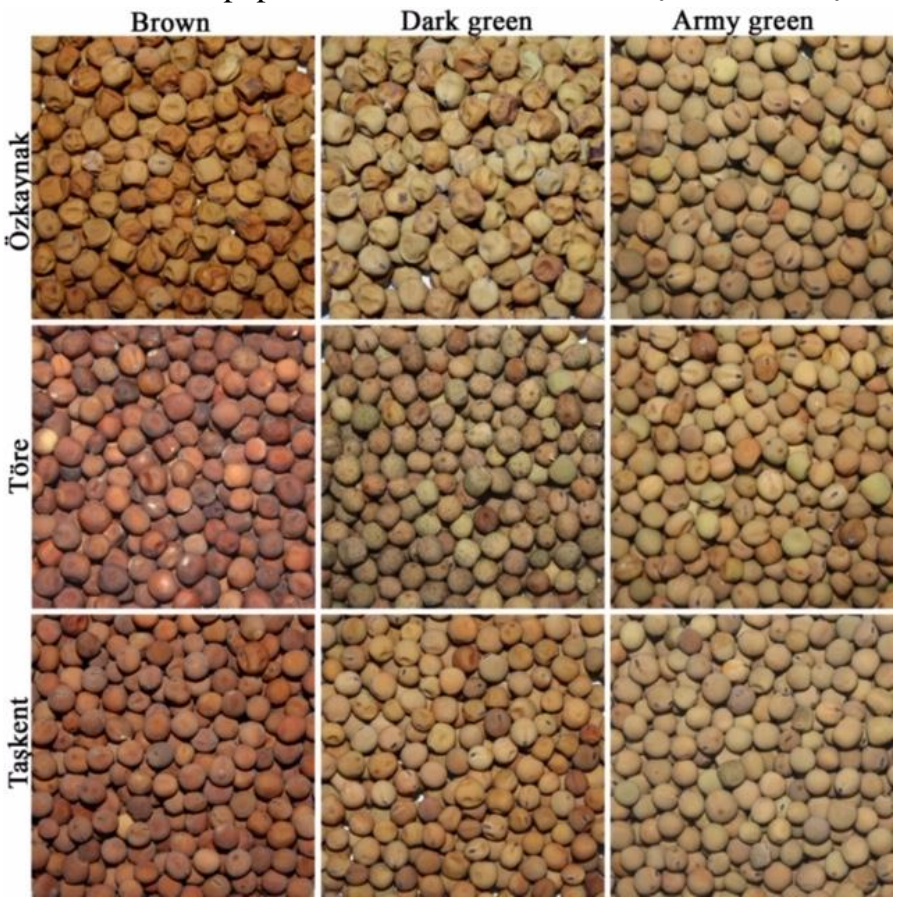

Figure 1

Seed coat colors of forage pea cultivars after visual separation.

Root length (RL), shoot length (SL), seedling fresh weight (SFW) and dry weight (SDW) were measured on the $10^{\text {th }}$ day.

Seed vigor of the seed color of forage pea was determined by two vigor tests. First, the electrical conductivity (EC) test was conducted with two replicates of 50 seeds from each cultivar and seed color. The seeds were firstly weighed and then soaked in $250 \mathrm{~mL}$ deionized water at $20^{\circ} \mathrm{C}$ for $24 \mathrm{~h}$. The EC of soaked water was measured using a conductivity meter (Model WTW Cond 314i, Germany) and the results were expressed in $\mu \mathrm{S} \mathrm{cm}^{-1} \mathrm{~g}^{-1}$ to evaluate the variability in seed weight (ISTA 2003). Second vigor test was accelerated ageing (AA) conducted with four replicates of $50 \mathrm{~g}$ seeds. It was performed by using an ageing temperature and time combination of $42^{\circ} \mathrm{C}$ for $48 \mathrm{~h}$ in a dark growth chamber (Atak et al. 2008). After incubation, $4 \times 50$ seeds were germinated between filter papers at $20^{\circ} \mathrm{C}$ in dark growth chamber for 10 days as described in germination test.

The experiment was designed as two factors factorial arranged in completely randomized design with four replications. The first factor was genotypes and the second was seed colors. Data for germination percentage were subjected to arcsine transformation before statistical analysis. Analysis of variance was performed using the MSTAT-C program (Michigan State University, v. 2.10). Significant differences among the mean values were compared by Duncan's Multiple Range test $(\mathrm{p}<0.05)$.

\section{Results and Discussion}

The main effects of forage pea cultivars, seed colors and analysis of variance with their significance levels for all the germination and seedling characteristics were described through Table 1. Among the forage pea cultivars, cv.Töre had the highest $2^{\text {nd }}$ day germination, final germination percentage, SL, SFW while it had the shortest MGT. There were significant differences among seed colors and the lighter colors (green and army green) resulted in the higher SL, RL, SFW and SDW. 
Table 1

Germination and seedling characteristics of three seed colors of three forage pea cultivars

\begin{tabular}{|c|c|c|c|c|c|c|c|c|}
\hline Factor & $\begin{array}{l}2^{\text {nd }} \text { day } \\
\text { GP }(\%)\end{array}$ & $\begin{array}{l}\text { FGP } \\
(\%)\end{array}$ & $\begin{array}{l}\text { MGT } \\
\text { (day) }\end{array}$ & $\begin{array}{c}\mathrm{SL} \\
(\mathrm{cm})\end{array}$ & $\begin{array}{l}\mathrm{RL} \\
(\mathrm{cm}) \\
\end{array}$ & $\begin{array}{c}\text { SFW } \\
\text { (mg/plant) }\end{array}$ & $\begin{array}{c}\text { SDW } \\
\text { (mg/plant) }\end{array}$ & $\begin{array}{l}\text { Electrical conductivity } \\
\qquad\left(\mu \mathrm{S} \mathrm{cm}^{-1} \mathrm{~g}^{-1}\right)\end{array}$ \\
\hline \multicolumn{9}{|c|}{ Cultivar } \\
\hline Özkaynak & $43.0^{b}$ & $96.6^{\mathrm{ab}}$ & $2.61^{\mathrm{a}}$ & $5.19^{\mathrm{b}}$ & 7.03 & $203^{\mathrm{b \dagger}}$ & 19.4 & 18.0 \\
\hline Töre & $67.8^{\mathrm{a}}$ & $98.6^{\mathrm{a}}$ & $2.32^{\mathrm{b}}$ & $7.01^{\mathrm{a}}$ & 7.46 & $243^{\mathrm{a}}$ & 20.1 & 19.3 \\
\hline Taşkent & $47.3^{\mathrm{b}}$ & $94.3^{\mathrm{b}}$ & $2.61^{\mathrm{a}}$ & $5.06^{\mathrm{b}}$ & 8.00 & $199^{\mathrm{b}}$ & 18.8 & 18.8 \\
\hline \multicolumn{9}{|c|}{ Seed color } \\
\hline Brown & $51.6^{\mathrm{ab}}$ & 96.5 & $2.51^{\mathrm{ab}}$ & $5.01^{\mathrm{b}}$ & $6.77^{\mathrm{b}}$ & $181^{\mathrm{b}}$ & $17.9^{\mathrm{b}}$ & $25.3^{\mathrm{a}}$ \\
\hline Green & $48.3^{\mathrm{b}}$ & 96.3 & $2.57^{\mathrm{a}}$ & $6.04^{\mathrm{a}}$ & $8.04^{\mathrm{a}}$ & $232^{\mathrm{a}}$ & $20.1^{\mathrm{a}}$ & $15.0^{\mathrm{b}}$ \\
\hline Army green & $58.1^{\mathrm{a}}$ & 96.8 & $2.45^{\mathrm{b}}$ & $6.20^{\mathrm{a}}$ & $7.68^{\mathrm{a}}$ & $232^{\mathrm{a}}$ & $20.2^{\mathrm{a}}$ & $15.7^{\mathrm{b}}$ \\
\hline \multicolumn{9}{|c|}{ Analysis of variance } \\
\hline Cultivar (C) & ** & $* *$ & ** & $* *$ & ns & $* *$ & ns & ns \\
\hline $\begin{array}{l}\text { Seed color } \\
\text { (SC) }\end{array}$ & $*$ & ns & $*$ & $* *$ & $* *$ & $* *$ & $* *$ & $* *$ \\
\hline $\mathrm{C} \times \mathrm{SC}$ & $* *$ & $\mathrm{~ns}$ & $* *$ & ** & $* *$ & $\mathrm{~ns}$ & $\mathrm{~ns}$ & $\mathrm{~ns}$ \\
\hline
\end{tabular}

*,**: significant at $5 \%$ and $1 \%$, respectively. GP: germination percentage, FGP: final germination percentage, MGT: mean germination time, SL: shoot length, RL: root length, SFW: seedling fresh weight, SDW: seedling dry weight

No significant changes in FGP was observed while $2^{\text {nd }}$ day germination was the highest in army green seeds $(58.1 \%)$. The electrical conductivity values were not affected by genotypes but it was varied by seed colors. Green and army green colored seeds gave lower EC values than brown ones. Similar these findings, Mandizvo and Odindo (2019) and At1s et al. (2011) reported that brown colored seeds indicated the lowest seed vigor and highest EC values than light ones in Bambara groundnut and red clover, respectively. However, Atak et al. (2005) stated that bleached pea seeds produced the minimum germination and the maximum EC value.

A two-way interaction (cultivar $\times$ seed color) was significant for $2^{\text {nd }}$ day GP, MGT, SL and RL ( $p<0.01$, Table 1). The army green seeds in Özkaynak and Taşkent gave the highest $2^{\text {nd }}$ day GP while Töre possessed it in brown seeds (Table 2). But, no significant differences between seed colors were determined. Contrarily, previous researches demonstrated that seed

Table 2

Germination and seedling properties as affected by the cultivars and seed colors

\begin{tabular}{|c|c|c|c|}
\hline \multicolumn{4}{|c|}{ Cultivar } \\
\hline Seed color & Özkaynak & Töre & Taşkent \\
\hline \multicolumn{4}{|c|}{$2^{\text {nd }}$ day germination percentage $(\%)$} \\
\hline Brown & $33.5^{\mathrm{f}}$ & $73.5^{\mathrm{a}}$ & $48.0^{\mathrm{cd} *}$ \\
\hline Green & $41.0^{\mathrm{de}}$ & $65.0^{\mathrm{b}}$ & $39.0^{\mathrm{ef}}$ \\
\hline Army green & $54.5^{\mathrm{c}}$ & $65.0^{\mathrm{b}}$ & $55.0^{\mathrm{c}}$ \\
\hline \multicolumn{4}{|c|}{ Mean germination time (day) } \\
\hline Brown & $2.74^{\mathrm{a}}$ & $2.26^{\mathrm{e}}$ & $2.55^{b}$ \\
\hline Green & $2.63^{\mathrm{ab}}$ & $2.34^{\mathrm{de}}$ & $2.76^{\mathrm{a}}$ \\
\hline Army green & $2.47^{\mathrm{bcd}}$ & $2.36^{\text {cde }}$ & $2.51^{\mathrm{bc}}$ \\
\hline \multicolumn{4}{|c|}{ Shoot length $(\mathrm{cm})$} \\
\hline Brown & $3.82^{\mathrm{e}}$ & $6.13^{b}$ & $5.09^{\mathrm{cd}}$ \\
\hline Green & $6.09^{\mathrm{b}}$ & $7.23^{\mathrm{a}}$ & $4.81^{\mathrm{d}}$ \\
\hline Army green & $5.66^{\mathrm{bc}}$ & $7.67^{\mathrm{a}}$ & $5.28^{\mathrm{cd}}$ \\
\hline \multicolumn{4}{|c|}{ Root length (cm) } \\
\hline Brown & $5.96^{\mathrm{d}}$ & $9.10^{\mathrm{a}}$ & $7.81^{b}$ \\
\hline Green & $8.01^{\mathrm{b}}$ & $8.22^{\mathrm{ab}}$ & $7.77^{\mathrm{b}}$ \\
\hline Army green & $6.35^{\mathrm{cd}}$ & $7.29^{\mathrm{bc}}$ & $7.45^{\mathrm{b}}$ \\
\hline
\end{tabular}

colors clearly affected germination percentage in pea (Atak et al. 2005), in guar (Liu et al. 2007) and in red clover (Atıs et al. 2011).

Cv.Taşkent with army green seeds led to a decrease obtained from brown seeds of cv.Töre without significance between seed colors. Similar results were observed by Atak et al. (2005) who determined faster germination in dark green colored pea seeds. Shoot length was significantly changed by seed color and the forage pea cultivars. Green and army green seeds of the cultivars had the longest SL, except for cv.Taşkent with green seeds (Table 2). The highest root length (RL) was recorded in brown seeds of cv. Töre with $9.10 \mathrm{~cm}$ and it was gradually decreased when the seed colors were green. However, no significant changes in RL of cv.Taşkent were determined among seed colors and green seeds of cv.Özkaynak gave longer RL than the other colors. time to germination while the fastest germination was

\footnotetext{
*: Means followed by same letter(s) are not significant at 5\%.
} 
All the investigated parameters after AA test were significantly different (Table 3 ). Higher $2^{\text {nd }}$ day germination and FGP were recorded in green and army green seeds. Cv.Töre indicated the superiority to the other cultivars in terms of the investigated parameters. Also, its seeds germinated faster than the others did. The seeds colored army green produced more vigorous seedling while mean germination time shortened in green and army green seeds. The study of Mandizvo and Odindo (2019) on structural and imbibitional characteristics of dark and light seed coat colors of Vigna subterranea L. landraces was confirmed by these findings. They reported that the light colored seed had the highest germination while the dark colored one had the lowest final germination after 120 hours of seed ageing.

Table 3

Germination and seedling properties as affected by the cultivars and seed colors after AA test

\begin{tabular}{|c|c|c|c|c|c|c|c|}
\hline Factor & $\begin{array}{c}2^{2^{\text {nd }}} \text { day GP } \\
(\%)\end{array}$ & $\begin{array}{l}\text { FGP } \\
(\%)\end{array}$ & $\begin{array}{l}\text { MGT } \\
\text { (day) }\end{array}$ & $\mathrm{SL}(\mathrm{cm})$ & $\mathrm{RL}(\mathrm{cm})$ & SFW (mg/plant) & SDW (mg/plant) \\
\hline \multicolumn{8}{|c|}{ Cultivar } \\
\hline Özkaynak & $35.0^{b}$ & $93.8^{b}$ & $2.84^{\mathrm{a}}$ & $5.21^{\mathrm{b}}$ & 6.32 & $188^{\mathrm{b}}$ & $16.8^{b}$ \\
\hline Töre & $58.6^{\mathrm{a}}$ & $98.0^{\mathrm{a}}$ & $2.42^{\mathrm{b}}$ & $6.40^{\mathrm{a}}$ & 6.55 & $217^{\mathrm{a}}$ & $18.1^{\mathrm{a}}$ \\
\hline Taşkent & $49.0^{\mathrm{a}}$ & $94.8^{\mathrm{b}}$ & $2.59^{\mathrm{b}}$ & $4.68^{c}$ & 5.85 & $176^{\mathrm{b}}$ & $15.4^{\mathrm{c}}$ \\
\hline \multicolumn{8}{|c|}{ Seed color } \\
\hline Brown & $37.1^{\mathrm{b}}$ & $89.6^{\mathrm{b}}$ & $2.77^{\mathrm{a}}$ & $4.85^{\mathrm{c}}$ & $5.63^{c}$ & $171^{\mathrm{b}}$ & $14.7^{\mathrm{c}}$ \\
\hline Green & $51.3^{\mathrm{a}}$ & $98.3^{\mathrm{a}}$ & $2.51^{\mathrm{b}}$ & $5.35^{\mathrm{b}}$ & $6.30^{\mathrm{b}}$ & $199^{\mathrm{a}}$ & $17.0^{\mathrm{b}}$ \\
\hline Army green & $54.1^{\mathrm{a}}$ & $98.6^{\mathrm{a}}$ & $2.57^{\mathrm{ab}}$ & $6.08^{\mathrm{a}}$ & $6.78^{\mathrm{a}}$ & $210^{\mathrm{a}}$ & $18.5^{\mathrm{a}}$ \\
\hline \multicolumn{8}{|c|}{ Analysis of variance } \\
\hline Cultivar (C) & $* *$ & $* *$ & $* *$ & $* *$ & ns & $*$ & $*$ \\
\hline Seed color $(\mathrm{SC})$ & $* *$ & $* *$ & $*$ & $* *$ & $* *$ & $* *$ & $* *$ \\
\hline $\mathrm{C} \times \mathrm{SC}$ & $* *$ & ns & $*$ & $* *$ & ns & $* *$ & ns \\
\hline
\end{tabular}

$*, * *$ : significant at $5 \%$ and $1 \%$, respectively. GP: germination percentage, FGP: final germination percentage, MGT: mean germination time, SL: shoot length, RL: root length, SFW: seedling fresh weight, SDW: seedling dry weight.

The $2^{\text {nd }}$ day GP after AA test was dissimilar to the germination test because army green seeds of cv. Töre gave the highest value of $74.0 \%$ (Table 4). Green colored seeds of Özkaynak and Taşkent germinated better than brown seeds. Also, time to germination retarded in brown seeds of forage pea cultivars and, green and army green seeds gave faster germination than brown seeds. The brown seeds had the lowest shoot length and seedling fresh weight and cv. Taşkent produce the lowest seedling growth.

Table 4

Germination and seedling properties by the cultivars and seed colors after AA test

\begin{tabular}{|c|c|c|c|}
\hline \multicolumn{4}{|c|}{ Cultivar } \\
\hline Seed color & Özkaynak & Töre & Taşkent \\
\hline \multicolumn{4}{|c|}{$2^{\text {nd }}$ day germination percentage $(\%)$} \\
\hline Brown & $14.0^{\mathrm{d}}$ & $51.5^{b}$ & $46.0^{\mathrm{bc} *}$ \\
\hline Green & $52.0^{\mathrm{b}}$ & $50.5^{\mathrm{b}}$ & $51.5^{\mathrm{b}}$ \\
\hline Army green & $39.0^{\mathrm{c}}$ & $74.0^{\mathrm{a}}$ & $49.5^{\mathrm{bc}}$ \\
\hline \multicolumn{4}{|c|}{ Mean germination time (day) } \\
\hline Brown & $3.14^{\mathrm{a}}$ & $2.51^{\mathrm{cd}}$ & $2.64^{\mathrm{bc}}$ \\
\hline Green & $2.50^{\mathrm{cd}}$ & $2.49^{\mathrm{cd}}$ & $2.55^{\mathrm{bcd}}$ \\
\hline Army green & $2.88^{\mathrm{ab}}$ & $2.27^{\mathrm{d}}$ & $2.58^{\mathrm{bcd}}$ \\
\hline \multicolumn{4}{|c|}{ Shoot length $(\mathrm{cm})$} \\
\hline Brown & $4.34^{\mathrm{d}}$ & $6.08^{\mathrm{bc}}$ & $4.15^{\mathrm{d}}$ \\
\hline Green & $5.57^{\mathrm{c}}$ & $6.37^{\mathrm{ab}}$ & $4.10^{\mathrm{d}}$ \\
\hline Army green & $5.72^{\mathrm{c}}$ & $6.75^{\mathrm{a}}$ & $5.78^{\mathrm{c}}$ \\
\hline \multicolumn{4}{|c|}{ Seedling fresh weight (mg/plant) } \\
\hline Brown & $142^{\mathrm{d}}$ & $207^{\mathrm{ab}}$ & $165^{\mathrm{c}}$ \\
\hline Green & $209^{\mathrm{ab}}$ & $229^{\mathrm{a}}$ & $158^{\mathrm{cd}}$ \\
\hline Army green & $212^{\mathrm{ab}}$ & $214^{\mathrm{ab}}$ & $204^{\mathrm{b}}$ \\
\hline
\end{tabular}

*: Means followed by same letter(s) are not significant at $5 \%$.

EC values of forage pea cultivars were similar to each other while seed colors gave different EC values. The higher EC value was measured in brown seeds but green and army green seeds gave lower EC values (Figure 2). No significant differences between EC values of green and army green seeds were determined.
Moreover, the results of AA test appeared in corroboration with EC test. Brown seeds after AA produced the lowest $2^{\text {nd }}$ day GP, FGP, seedling growth and retarded germination time. 


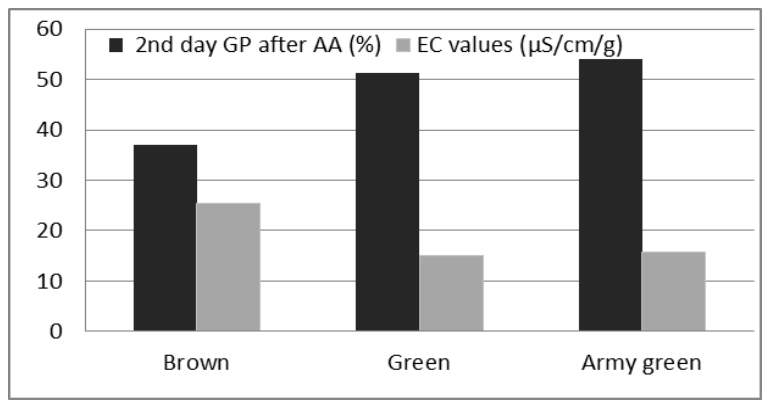

Figure 2

EC values and $2^{\text {nd }}$ day germination percentage after AA test of brown, green and army green seeds of forage pea.

In conclusion, seed color is an indicator of seed vigor in forage pea cultivars and the darker seeds produced a delayed germination and restricted seedling growth. However, forage pea genotypes showed different responses to seed color and cv. Taşkent did not show the sensitivity to seed colors. It should be advised that the seed lots after harvest should be selected for seed color to attain vigorous seeds, better germination performance and seedling growth in forage pea cultivars.

\section{References}

Acikgoz E (2001). Yem Bitkileri. Uludağ Üniversitesi, Yayın No: 182, Bursa, Turkey. s. 584.

Anuradha R, Balamurugan P, Srimathi P, Sumathi S (2009) Influence of seed coat colour variations on seed quality in Bengalgram cv. Co 4 (Cicer arietinum L.). Legume Research 32(2): 136-138.

Atak M, Kaya MD, Kaya G, Kaya M, Khawar KM (2008). Dark green colored seeds increase the seed vigor and germination ability in dry green pea $(P i$ sum sativum L.). Pakistan Journal of Botany 40(6): 2345-2354.

Atis I, Atak M, Can E, Mavi K (2011). Seed coat color effects on seed quality and salt tolerance of red clover (Trifolium pratense). International Journal of Agriculture and Biology 13(3): 363-368.

Bhatt A, Gairola S, El-Keblawy AA (2016). Seed colour affects light and temperature requirements during germination in two Lotus species (Fabaceae) of the Arabian subtropical deserts. Revista De Biologia Tropical 64 (2): 483-492.

Ertekin M, Kirdar E (2010). Effects of seed coat colour on seed characteristics of honeylocust (Gleditsia triacanthos). African Journal of Agricultural Research 5(17): 2434-2438.

ISTA (2003). International Rules for Seed Testing. Edition 2003. International Seed Testing Association. Bassersdorf, Switzerland.

Liu W, Peffley EB, Powell RJ, Auld DL, Hou A (2007) Association of seedcoat color with seed water uptake, germination, and seed components in guar (Cyamopsis tetragonoloba (L.) Taub). Journal of Arid Environments 70: 29-38.

Mandizvo T, Odindo AO (2019). Seed coat structural and imbibitional characteristics of dark and light coloured Bambara groundnut (Vigna subterranea L.) landraces. Heliyon 5: e01249. doi: 10.1016/j.heliyon.2019. e01249.

Mishra MK, Dubey RK, Rao SK (2010). Nutritional composition of field pea (Pisum sativum var arvense L.). Legume Research 33(2):146-147.

Parr M, Grossman JM, Reberg-Horton SC, Brinton C, Crozier C (2011). Nitrogen delivery from legume cover crops in no-till organic corn production. Agronomy Journal 103 (6): 1578-1590. doi: 10.2134/agronj2011.0007.

Santos CS, Carbas B, Castanho A, Vasconcelos MW, Patto MCV, Domoney C, Brites C (2019). Variation in pea (Pisum sativum L.) seed quality traits defined by physicochemical functional properties. Foods 8: 570. doi:10.3390/foods8110570.

Tan M, Koc A, Dumlu Gul Z (2012). Morphological characteristics and seed yield of East Anatolian local forage pea (Pisum sativum ssp. arvense L.) ecotypes. Turkish Journal of Crop Science 17(1): 2430.

TUİK (2018). Türkiye İstatistik Kurumu Bitkisel Üretim İstatistikleri. http://www.tuik.gov.tr/PreTablo.do?alt_id=1001.

Uzun A, Gun H, Acikgoz, E (2012). Yield and quality characteristics of some pea (Pisum sativum L.) varieties harvested at different growing stages. Journal of Agricultural Faculty of Uludag University, 26(1), 27-38. 